\title{
Antimicrobial activity of bovine $\beta$-lactoglobulin against mastitis-causing bacteria
}

\author{
L. Chaneton, ${ }^{1}$ J. M. Pérez Sáez, ${ }^{2}$ and L. E. Bussmann \\ Instituto de Biología y Medicina Experimental, CONICET 1428, Buenos Aires, Argentina
}

\begin{abstract}
Bovine mastitis is one of the most economically deleterious diseases affecting dairy herds. It results from an infection of the udder by pathogenic microorganisms such as Staphylococcus aureus, Streptococcus uberis, and Escherichia coli. The mammary gland is capable of preventing and combating bacterial infection by means of a complex network of innate and adaptive immune mechanisms. Lactoferrin is an $86-\mathrm{kDa}$ protein with antibacterial activity that plays a role in the mammary gland's defense against infection. $\beta$-Lactoglobulin $(\beta-\mathrm{LG})$ is an $18-\mathrm{kDa}$ protein that is present in most mammals but is notably absent in humans, rodents, and lagomorphs. There are different genetic variants of this protein, with $\beta$-LG A and $\beta$-LG B being the most common. In spite of being well studied, the biological function of $\beta-\mathrm{LG}$ is not thoroughly understood, and most noticeably, there are no reports on the effects of the native protein on bacterial growth. Hence, the objective of this study was to assess the potential antibacterial activity of $\beta$-LG against mastitis agents. To do this, we purified $\beta$-LG from normal bovine milk using a mild, nondenaturing method and performed in vitro growth inhibition assays with Staph. aureus, E. coli, and Strep. uberis. $\beta$-Lactoglobulin inhibited the growth of Staph. aureus and Strep. uberis but had no effect on E. coli. The antimicrobial activity against Staph. aureus and Strep. uberis was concentration dependent and was elicited by the intact protein because Tricine-sodium dodecyl sulfate-PAGE and analytical gel filtration chromatography did not reveal the presence of short degradation peptides. Analysis of the genetic variants of $\beta$-LG showed that $\beta$-LG A has higher inhibitory activity against Staph. aureus and Strep. uberis than $\beta-\mathrm{LG}$ B. Coincubation of $\beta-\mathrm{LG}$ and lactoferrin resulted in an augmented antibacterial activity against Staph. aureus, suggesting an additive effect of the proteins.
\end{abstract}

\footnotetext{
Received April 6, 2010.

Accepted September 16, 2010.

${ }^{1}$ Corresponding author: chaneton@dna.uba.ar

${ }^{2}$ Present address: Bio-Sidus S.A., Constitución 4234, 1254 Buenos Aires, Argentina.
}

This result, along with the proteins' complementary spectrum of action, suggests that $\beta$-LG and lactoferrin may complement each other in the mammary gland's defenses against bacterial infection.

Key words: antimicrobial, $\beta$-lactoglobulin, mastitiscausing bacteria

\section{INTRODUCTION}

Bovine mastitis is the most prevalent and costly disease affecting dairy farms. Economic losses associated with mastitis derive mainly from a decrease in milk production and, to a lesser extent, from the culling of chronically infected cows, cost of veterinary treatment, and penalties on milk quality (Seegers et al., 2003). Mastitis is caused by a wide spectrum of pathogenic agents that can penetrate the teat canal and multiply in the udder cistern. More than 130 microorganisms have been reported to infect the bovine mammary gland (Watts, 1988). However, the vast majority of mastitis cases are produced by a relatively small group of gramnegative and gram-positive bacteria, including Staphylococcus aureus, Streptococcus uberis, and Escherichia coli (Calvinho and Tirante, 2005). Intramammary infection can be accompanied by the development of symptoms such as swelling, redness, udder pain, or clots in the milk (clinical mastitis), but it also can lack such symptoms and be detectable only with microbiological or biochemical analysis (subclinical mastitis). The mammary gland responds to pathogen invasion with cellular and soluble factors of the innate and adaptive immune systems, which act in a highly coordinated fashion (Sordillo and Streicher, 2002; Oviedo-Boyso et al., 2007).

Lactoferrin $(\mathbf{L F})$ is an $86-\mathrm{kDa}$ glycoprotein found in milk and other barrier fluids of most mammal species that possesses bacteriostatic and bactericidal activities (Arnold et al., 1982; Rainard, 1986). We and others previously reported that LF concentration in bovine milk increases upon clinical or subclinical infection and that many mastitis-causing bacteria are susceptible to LF in vitro (Kutila et al., 2003; Chaneton et al., 2008). These observations led to the notion that LF plays a pivotal role in mammary gland defenses against masti- 
tis. In addition, the interaction of LF with other soluble factors of mammary gland immunity has been reported to increase its antibacterial activity (Spik et al., 1978; Ellison and Giehl, 1991).

$\beta$-Lactoglobulin is the major protein found in the whey of ruminants $(2-3 \mathrm{~g} / \mathrm{L})$, but it is absent in humans, rodents, and lagomorphs. $\beta$-Lactoglobulin is a member of the lipocalin protein superfamily (Sawyer and Kontopidis, 2000). It has the 8 -stranded $\beta$ barrel tertiary structure typical of this family and closely resembles the human retinol-binding protein (Flower et al., 2000). It is anionic, with a pI of approximately 5 and a molecular weight of 18,280 Da, and it exists as a dimer at physiological temperature and $\mathrm{pH}$.

Different genetic variants of $\beta-\mathrm{LG}$ exist, among which $\mathrm{A}$ and $\mathrm{B}$ are predominant; $\beta$-LG $\mathrm{B}$ differs from $\beta$-LG A by 2 AA substitutions (Asp 64 for Gly and Val 118 for Ala). These variants have been associated with differences in the protein yield and industrial-processing properties of milk (Bovenhuis et al., 1992; Qin et al., 1999; Heck et al., 2009). Many biological functions have been proposed for $\beta$-LG (Kontopidis et al., 2004), including retinol and fatty acid transport (Pérez and Calvo, 1995), improvement of lipid digestion (Pérez et al., 1992), and passive immune transfer (Ouwehand et al., 1997). Pellegrini et al. (2004) described the antibacterial activity of 4 peptides derived from a trypsin digestion of $\beta$-LG, which led to a proposed biological function for this protein in newborn calves. In spite of being extensively studied, whether the intact $\beta$-LG protein has a biological function in the mammary gland is not known. This prompted us to study the possible antibacterial effect of $\beta$-LG against the major bacterial agents involved in bovine mastitis. In this article, we present evidence that the intact $\beta$-LG protein possesses antibacterial activity against Staph. aureus and Strep. uberis, but not against E. coli. This spectrum of antimicrobial activity differs from that observed for $\mathrm{LF}$, which is effective against $E$. coli but has no effect on Strep. uberis. Given that $\beta-\mathrm{LG}$ and LF have different effects on Strep. uberis and E. coli and an additive effect against Staph. aureus, our results suggest that these proteins play complementary roles in the defense of the mammary gland against bacterial infection.

\section{MATERIALS AND METHODS}

\section{Pathogen Isolation and Identification}

Isolation of mastitis-causing bacteria was performed in Lactodiagnóstico Sur (Buenos Aires, Argentina). The bacterial isolates used in this study were obtained from multiparous Holstein cows randomly chosen from pasture-based herds with low SCC milk $(<150,000$ cells $/ \mathrm{mL}$ ). For pathogen isolation, foremilk from udders that did not show external signs of infection was aseptically collected and maintained at $4^{\circ} \mathrm{C}$ until cultured. When samples could not be processed within $24 \mathrm{~h}$ of collection, they were frozen at $-18^{\circ} \mathrm{C}$ (Schukken et al., 1989). Samples were cultured by plating $0.05 \mathrm{~mL}$ of milk on blood-esculin agar plates and incubating for 24 to $48 \mathrm{~h}$ at $37^{\circ} \mathrm{C}$. Simultaneously, an aliquot of the sample was incubated for $4 \mathrm{~h}$ at $37^{\circ} \mathrm{C}$ and then plated on blood-esculin agar to recover pathogens present at low concentrations (Dinsmore et al., 1992). Isolation and identification of bacteria were performed according to the recommendations of the National Mastitis Council (Hogan et al., 1999).

\section{$\beta-L G$ and Lactoferrin Purification}

Bovine lactoferrin was purified from the milk of healthy Holstein, multiparous cows as described previously (Chaneton et al., 2008). A mild isolation method based on the protocol described by de Jongh et al., (2001) was used for $\beta$-LG purification. Briefly, bovine milk was processed within $6 \mathrm{~h}$ after milking. Five hundred milliliters of milk was centrifuged at 10,000 $\times g$ for $20 \mathrm{~min}$ at $4^{\circ} \mathrm{C}$ for delipidation. The $\mathrm{pH}$ of the skim milk was adjusted to $\mathrm{pH} 4.5$ by the addition of $10 \mathrm{~N}$ $\mathrm{HCl}$; the solution was stirred for 30 min to complete precipitation and then centrifuged at $15,000 \times g$ for $30 \mathrm{~min}$ at $4^{\circ} \mathrm{C}$ for casein removal. The resulting whey was neutralized, $30 \mathrm{~mL}$ of DEAE Sepharose anionic exchange resin was added (GE Healthcare, Piscataway, $\mathrm{NY}$ ) in $0.1 M$ phosphate buffer ( $\mathrm{pH} 7.0$ ), and incubation was allowed to proceed overnight at $4^{\circ} \mathrm{C}$ with constant agitation. The resin was recovered by decantation, washed twice with $0.1 M$ phosphate buffer ( $\mathrm{pH} 7.0$ ), and packed in a $2.5-\mathrm{cm}$ diameter column. The column was extensively washed with $0.1 \mathrm{M} \mathrm{NaCl}$ in phosphate buffer (pH 7.0), and $\beta$-LG was eluted with $0.25 \mathrm{M} \mathrm{NaCl}$ in phosphate buffer ( $\mathrm{pH}$ 7.0). The eluate was placed in a dialysis bag, concentrated in Aquacide II (Calbiochem, La Jolla, CA), and dialyzed against PBS. The concentrated and dialyzed sample was then subjected to gel-filtration chromatography in a Superdex 75 (GE Healthcare) equilibrated with PBS and eluted with the same buffer. The fractions with retention times corresponding to the $36-\mathrm{kDa} \beta-\mathrm{LG}$ dimer, according to a molecular weight standard, were collected. The purity of the obtained $\beta$-LG was confirmed by silver-stained SDS-PAGE (Laemmli, 1970) loading $2 \mu \mathrm{g}$ of purified protein per lane. The identity of $\beta-\mathrm{LG}$ was confirmed by Western blotting, loading $0.1 \mu \mathrm{g}$ of purified protein per lane, with anti- $\beta-\mathrm{LG}$ antibodies (Bethyl Laboratories Inc., Montgomery, TX). Genotype identification was based on the differential mobility of $\beta-L G$ variants 
when resolved in a nondenaturing 15\% PAGE (Ye et al., 2000). Tris-tricine 16\% SDS-PAGE of the obtained protein was performed as described previously (Schägger and von Jagow, 1987). The identity and purity of the purified protein also was confirmed by a protein mass analysis using reverse-phase HPLC coupled with mass spectrometry (RP-HPLC-MS) and peptide mass fingerprint by matrix-assisted laser desorption/ ionization time of flight-time of flight (MALDI-TOFTOF) after tryptic digestion. Briefly, protein were analyzed by RP-HPLC-MS using a $1.0 \mathrm{~mm} \times 30 \mathrm{~mm}$ Vydac C8 column, operating at $40 \mu \mathrm{L} / \mathrm{min}$, connected to a Surveyor HPLC system online with an LCQ Duo (ESI ion trap) mass spectrometer (Thermo Fisher, San Jose, CA). Protein was eluted using a 15-min gradient from 10 to $100 \%$ solvent B (solvent A: $2 \%$ acetic acid, $2 \%$ acetonitrile; solvent B: $2 \%$ acetic acid, $96 \%$ acetonitrile). Protein characterization was performed by full scan from 300 to 2,000 amu and ProMass deconvolution program. For peptide mass fingerprint, protein of interest was first reduced with dithiothreitol and cysteines carboxymethylated. The protein was cleaved in solution with trypsin, and the mass peptides measured in a MALDI TOF-TOF 4800 plus (ABSciex) in reflectron mode. The masses lists were compared with Swiss Prot database, using Mascot software PMF. The results were statistically analyzed to find the best match. Mass spectrometric analyses were performed by the National Laboratory of Research and Services in Proteins and Peptides (Bueños Aires, Argentina).

\section{Microbiological Assays}

Four isolates each of Strep. uberis, Staph. aureus, and $E$. coli obtained as described above were employed in this study. Mastitis-causing bacteria were isolated and identified following the National Mastitis Council guidelines (Hogan et al., 1999). All bacteria were maintained in glycerol medium at $-80^{\circ} \mathrm{C}$, thawed, and plated into peptone yeast extract agar plates before experimental procedures. Working inocula of bacteria were prepared by subculturing single colonies from these plates into peptone yeast extract broth and incubating them for $16 \mathrm{~h}$. After incubation, $0.02 \mathrm{~mL}$ of each culture was inoculated into $2 \mathrm{~mL}$ of fresh peptone yeast extract broth and further incubated for $3 \mathrm{~h}$ at $37^{\circ} \mathrm{C}$. The resulting culture was then diluted in saline to approximately $4 \times 10^{4} \mathrm{cfu} / \mathrm{mL}$, and the suspension was used as follows. To each microtube, we added 12 $\mu \mathrm{L}$ of antibiotic medium $[0.15 \%(\mathrm{vol} / \mathrm{vol})$ meat extract, $0.15 \%$ ( $\mathrm{vol} / \mathrm{vol}$ ) yeast extract, $0.5 \%$ ( vol/vol) peptone, $0.1 \%$ ( vol/vol) dextrose, $0.35 \%$ ( vol/vol) NaCl, $0.37 \%$ (vol/vol) $\mathrm{K}_{2} \mathrm{HPO}_{4}, 0.13 \%$ (vol/vol) $\mathrm{KH}_{2} \mathrm{PO}_{4}$; Difco, Detroit, MI], $4 \mu \mathrm{L}$ of the protein to be tested at 5 times the final concentration used in each experiment, and 4 $\mu \mathrm{L}$ of bacterial inoculum ( 160 cfu). Growth controls contained sterile water in place of the protein solution. Cultures were allowed to proceed for $6 \mathrm{~h}$, and bacterial colony-forming units per milliliter was then assessed in control and treatment tubes in triplicate by standard colony counting on peptone yeast extract agar plates.

\section{Experimental Design and Statistical Analyses}

Four independent isolates each of Strep. uberis, Staph. aureus, and E. coli were used in this study. Each experiment was performed in triplicate. A general linear model was used to analyze the effect of $\beta-L G$ and LF on bacterial growth. $\beta$-Lactoglobulin and LF treatment were added as fixed effects and pathogen isolate was the random effect. Dunnett's test was used as a posthoc test to evaluate differences between $\beta$-LG and LF treated and control groups. A similar general linear model was used to evaluate the effect of $\beta$-LG A and $\beta$-LG $\mathrm{B}$ and the combination of $\beta$-LG $\mathrm{A}$ and LF on bacterial growth with a Bonferroni test as a post-hoc test. The concentration dependence of $\beta-\mathrm{LG}$ on the growth of Strep. uberis and Staph. aureus was evaluated in a multiple linear regression model incorporating $\log _{10} \mathrm{cfu} / \mathrm{mL}$ and $\beta$-LG concentration as a response and explicative variable respectively. Pathogen isolates were added as a dummy variable in this regression model.

All statistical analyses were performed with SPSS 15 for Windows (SPSS Inc., Chicago, IL).

\section{RESULTS}

To preserve the structural integrity of $\beta$-LG, a mild, nondenaturing purification method was used to isolate $\beta$-LG from fresh milk (see Materials and Methods). The milk was processed within $6 \mathrm{~h}$ of milking to avoid denaturation or degradation of $\beta$-LG. According to previous studies conducted by our group, the most frequent genotype of $\beta$-LG in Argentina is homozygous at the B allele (Gigli et al., 2004). Consequently, we decided to begin our research with $\beta-L G$ isolated from cows with $\beta$-LG homozygous at the B allele. Genotype identification was performed based on the differential mobility of $\beta$-LG variants when resolved in nondenaturing $15 \%$ PAGE (Figure 1A; Ye et al., 2000). The isolated $\beta-\mathrm{LG}$ was first analyzed by silver-stained SDS-PAGE and Western blot (Figure 1B). The identity and purity of the purified $\beta-L G$ was further evaluated by protein mass determination by means of RP-HPLC-MS, and peptide mass fingerprint by MALDI-TOF-TOF. Molecular mass as determined by RP-HPLC-MS was in agreement with the theoretical mass of $\beta$-LG. Peptide mass fingerprint showed the presence of peptides cor- 
responding only to the sequence of this protein (match score 111). No contaminating peptides were detected in this analysis.

To evaluate the potential antibacterial activity of $\beta$-LG B against mastitis-causing bacteria, we used $\beta$-LG B in growth-inhibition assays of Staph. aureus, Strep. uberis, and E. coli isolated from subclinically infected mammary quarters. Lactoferrin was also included in the assays as a control antimicrobial protein. $\beta$-Lactoglobulin inhibited the growth of Staph. aureus at levels comparable to LF (Figure 2A). Although $\beta$-LG also inhibited Strep. uberis, LF had no effect on it (Figure 2B). Escherichia coli was unaffected by $\beta$-LG, but was sensitive to LF (Figure 2C). Variability in the

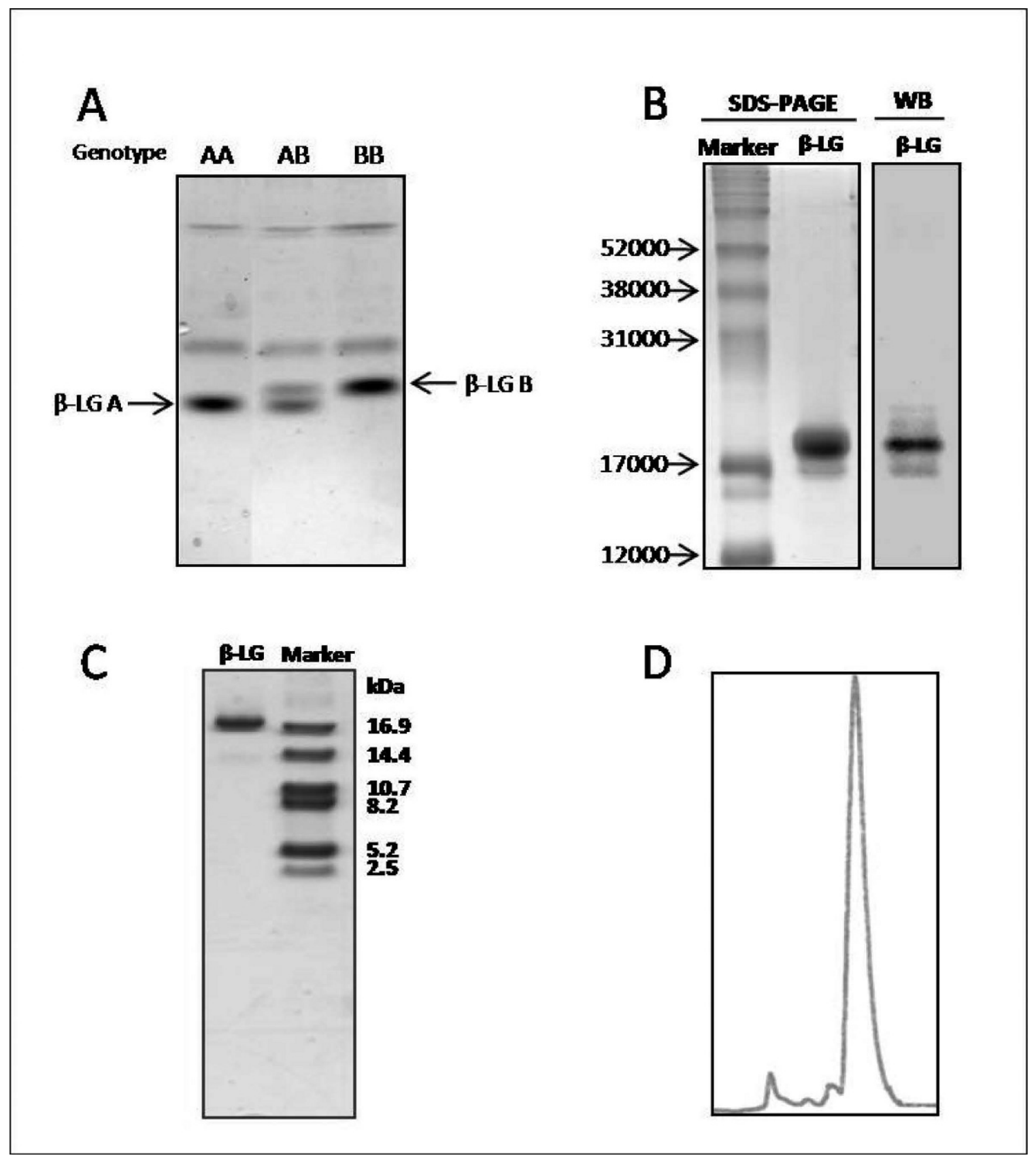

Figure 1. Purification of $\beta-\mathrm{LG}$ from fresh bovine milk. (A) Whey from cows of 3 genotypes was resolved in nondenaturing PAGE: homozygous for allele A, heterozygous, and homozygous for allele B. Differences in the electrophoretic mobility of the 2 genetic variants of $\beta$-LG can be observed. (B) Purified bovine LG was resolved in 15\% SDS-PAGE and silver stained for purity analysis or subjected to Western blotting (WB) with a commercial anti- $\beta$-LG antibody to confirm its identity. Purified $\beta$-LG was resolved in (C) $16.5 \%$ Tricine-SDS-PAGE or (D) subjected to analytical gel filtration chromatography to verify the absence of short peptides and degradation products. 
A

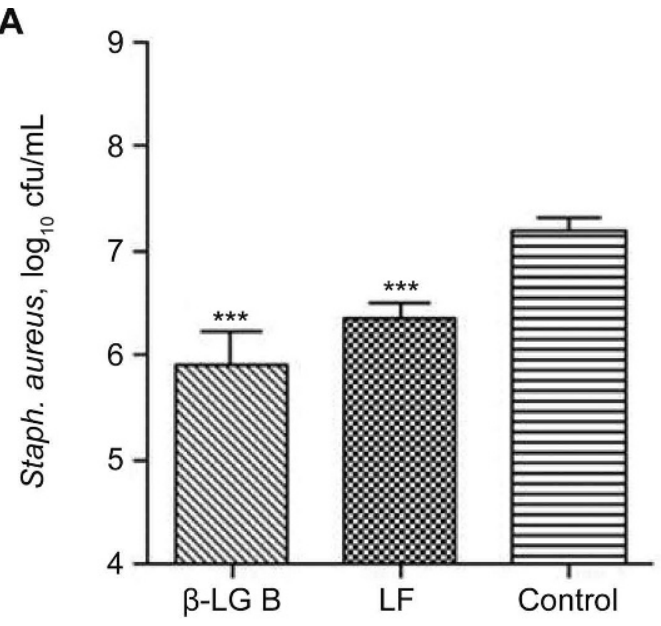

B
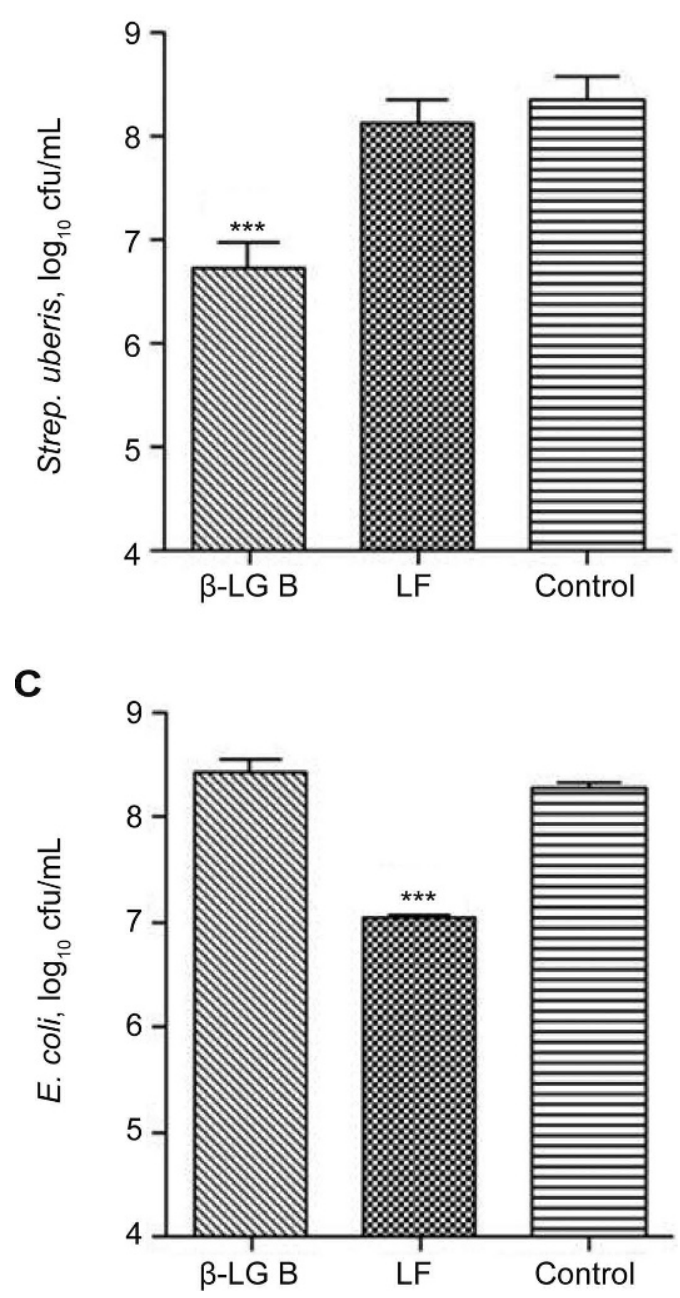

Figure 2. Growth-inhibitory activity of $\beta-\mathrm{LG}$ and lactoferrin (LF) against mastitis-causing bacteria. Four local isolates of mastitiscausing (A) Staphylococcus aureus, (B) Streptococcus uberis, and (C) Escherichia coli were cultured in the presence of $2 \mathrm{mg} / \mathrm{mL}$ of $\beta$-LG B, $2 \mathrm{mg} / \mathrm{mL}$ of LF, or under control conditions. Bacterial counts (cfu) $\mathrm{mL}$ ) were assessed after $6 \mathrm{~h}$ of growth. Columns represent the mean \pm SEM; ${ }^{* * *} P<0.001$.
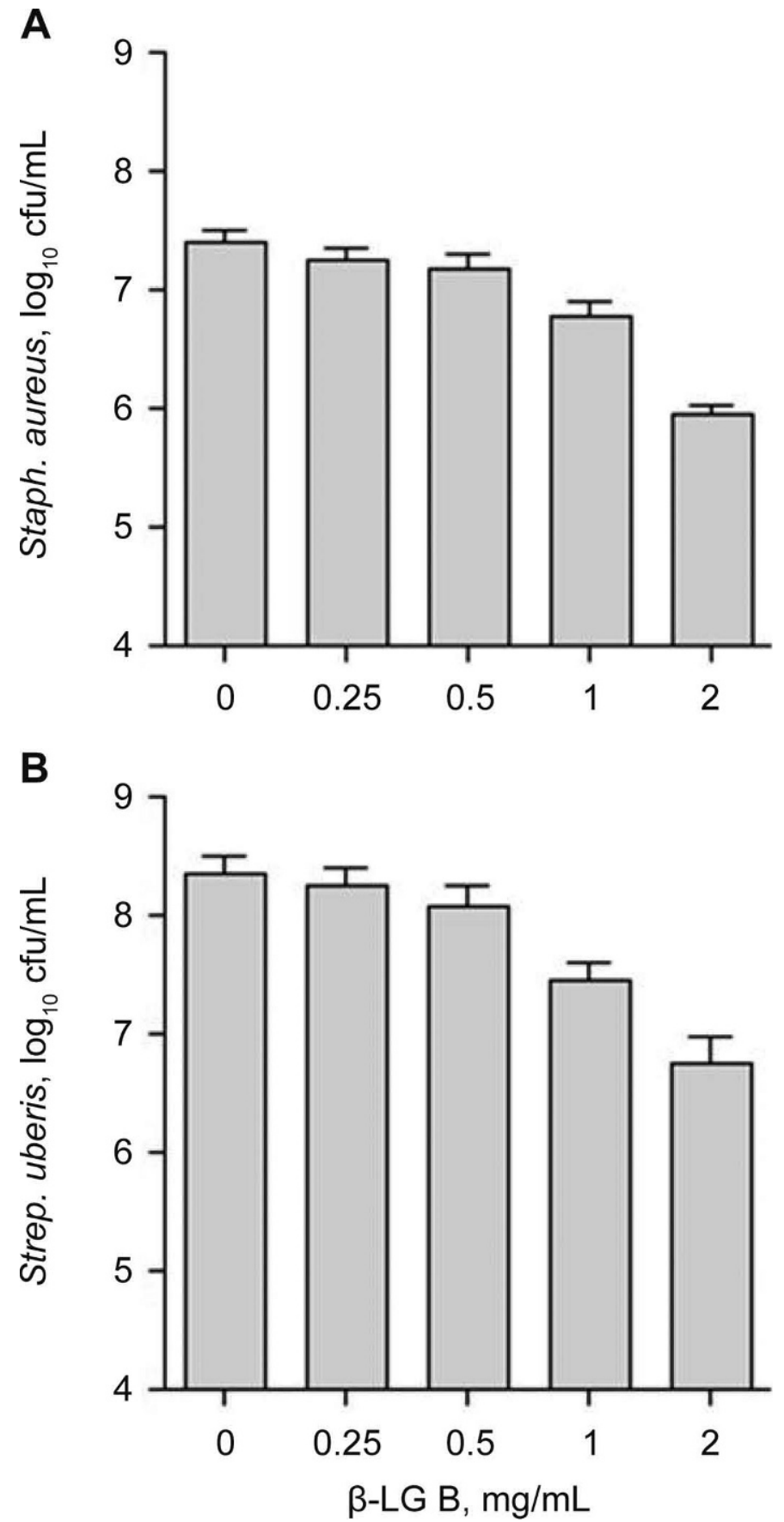

Figure 3. Concentration-dependent activity of $\beta$-LG. (A) Staphylococcus aureus and (B) Streptococcus uberis were cultured with varying concentrations of $\beta$-LG or in the absence of $\beta$-LG. Bacterial counts $(\mathrm{cfu} / \mathrm{mL})$ were assessed after $6 \mathrm{~h}$ of growth. Columns represent the mean \pm SEM.

response to $\beta$-LG and b-LF was observed among the different isolates of each species.

We also conducted growth-inhibition experiments with different concentrations of $\beta-\mathrm{LG}$ B. The inhibitory action of $\beta$-LG B on Staph. aureus and Strep. uberis 
A

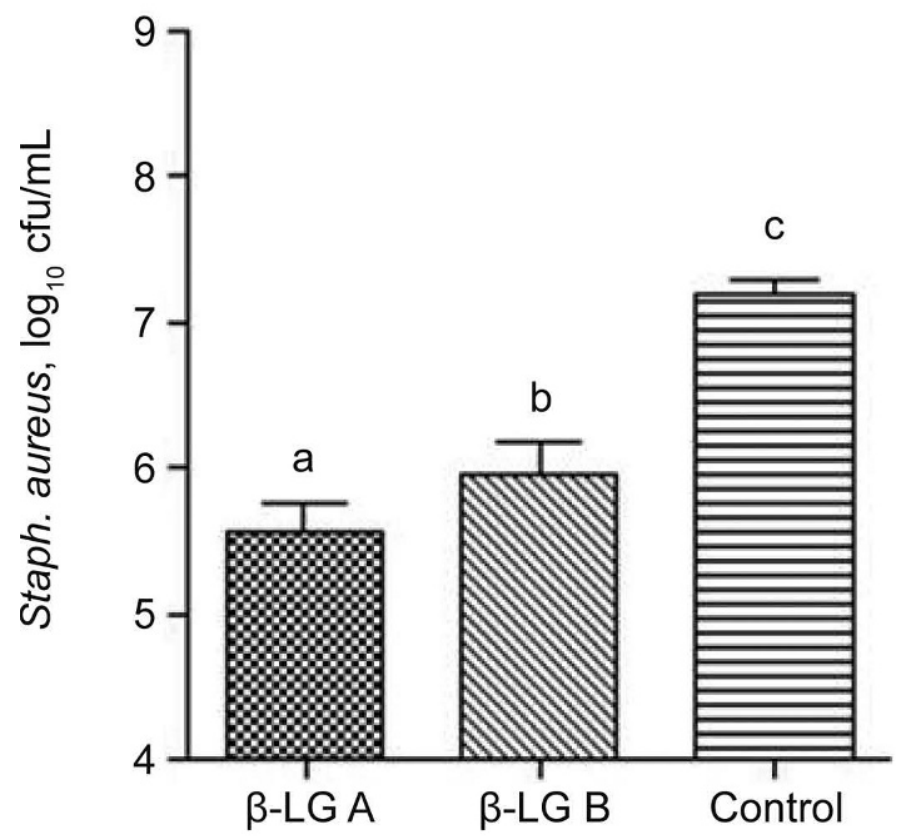

B

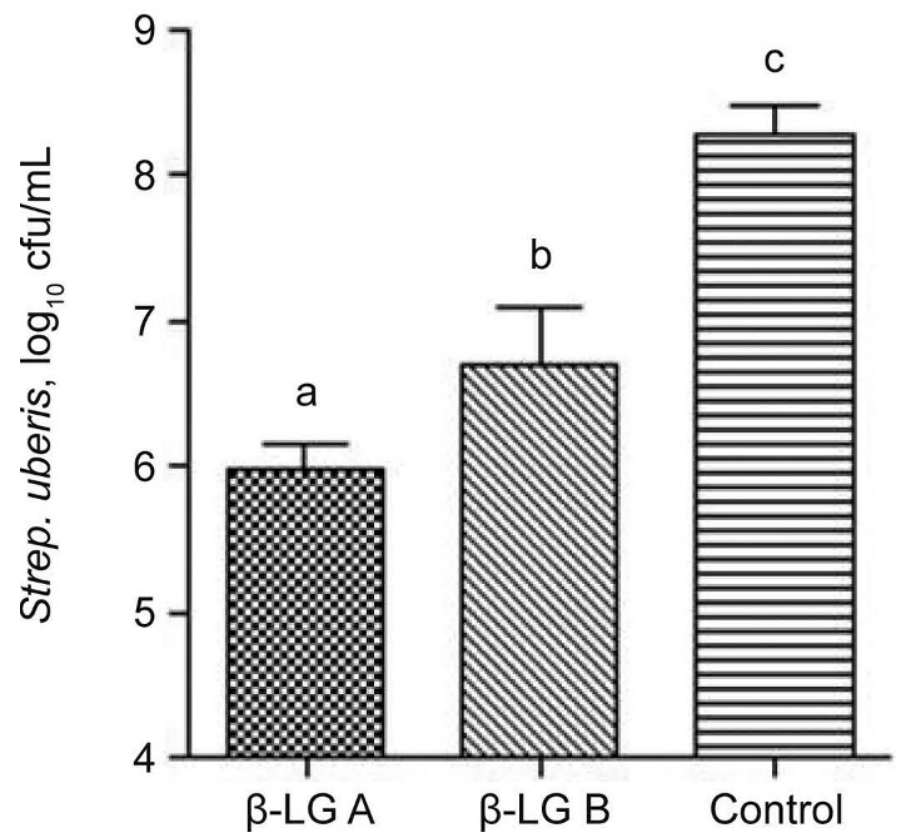

Figure 4. Antimicrobial activity of the genetic variants of $\beta$-LG. Four local isolates of mastitis-causing (A) Staphylococcus aureus or (B) Streptococcus uberis were cultured with $2 \mathrm{mg} / \mathrm{mL}$ of $\beta-\mathrm{LG}$ isolated from homozygous BB cows ( $\beta$-LG B) or homozygous AA cows $(\beta$ LG A). Bacterial counts (cfu/mL) were assessed after $6 \mathrm{~h}$ of growth. Columns represent the mean \pm SEM, and different letters indicate significant differences $(P<0.001)$.

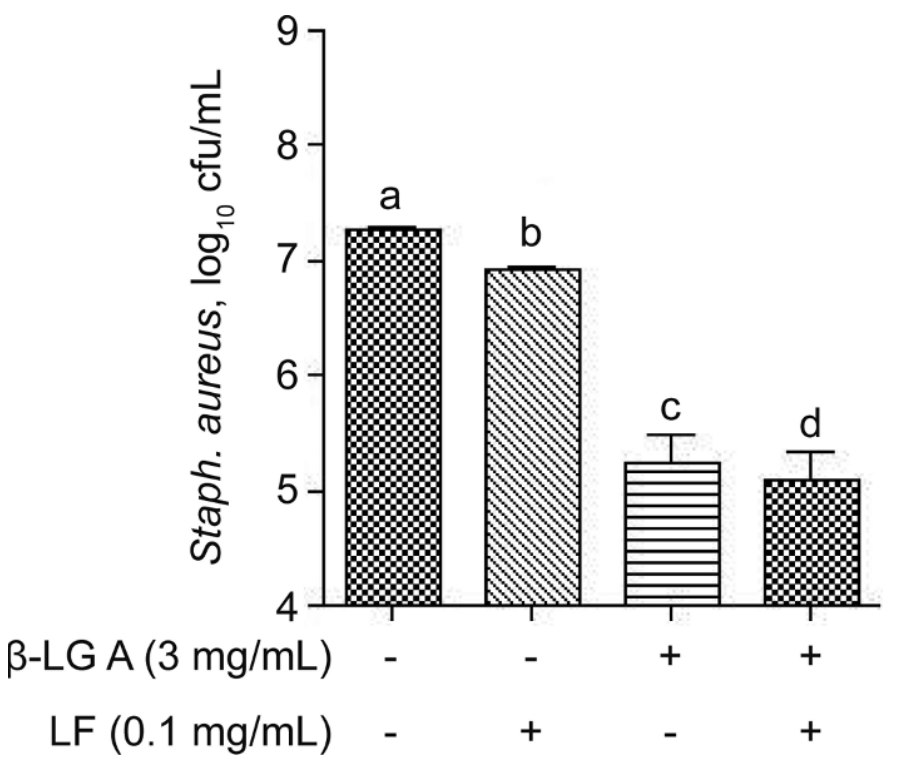

Figure 5. Coincubation of $\beta-\mathrm{LG}$ and lactoferrin (LF). Four local isolates of mastitis-causing Staphylococcus aureus were cultured with $3 \mathrm{mg} / \mathrm{mL}$ of $\beta-\mathrm{LG}, 0.1 \mathrm{mg} / \mathrm{mL}$ of $\mathrm{LF}$, both proteins, or control conditions. Bacterial counts $(\mathrm{cfu} / \mathrm{mL})$ were assessed after $6 \mathrm{~h}$ of growth. Columns represent the mean \pm SEM. Different letters indicate significant differences $(P<0.001)$, except a versus b $(P<0.05)$.

displayed a concentration-dependent pattern, with the slope of the $\log$-cfu/mL vs. $\beta$-LG B regression being significantly different from $0(P<0.0001)$ for both microorganisms (Figure 3).

To rule out the possibility that the observed effect of $\beta-L G$ B was mediated by short peptides resulting from protein degradation, we resolved our $\beta$-LG B preparation in tricine-SDS-PAGE (16.5\%). A sharp $\beta$-LG B band and a lack of protein-degradation products were noted (Figure 1C). Additionally, we confirmed the lack of $\beta$-LG-derived peptides using analytical gel filtration chromatography (Figure 1D).

Because there are many genetic variants of $\beta-\mathrm{LG}$, we decided to study the potential differences in their antimicrobial activity against Staph. aureus and Strep. uberis. To do this, we purified $\beta$-LG from cows that were homozygous at the $\beta$-LG A allele, and we compared its antimicrobial activity with that of $\beta$-LG B isolated from cows homozygous at the $\beta$-LG B allele. The $\beta$-LG A variant showed significantly more antimicrobial activity against both Staph. aureus and Strep. uberis than $\beta$-LG B (Figure 4).

In light of the fact that both LF and $\beta-\mathrm{LG}$ have antibacterial activity against Staph. aureus, we tested the hypothesis that these proteins could act together to impair the growth of Staph. aureus in the bovine mammary gland. We coincubated Staph. aureus isolates from mastitic milk with $\beta$-LG A and LF using concentrations of both proteins that were similar to 
those found in bovine milk during mid lactation. The addition of LF produced a significant increase in the inhibitory capacity of $\beta$-LG A against Staph. aureus, indicating an additive effect of the 2 proteins on bacterial growth (Figure 5).

\section{DISCUSSION}

In spite of $\beta$-LG being a well-studied protein, its biological function is still a matter of debate (Kontopidis et al., 2004). In this article, we report that native $\beta$-LG possesses antibacterial activity in vitro toward Strep. uberis and Staph. aureus, but not E. coli. Three of the most prevalent pathogens of the mammary gland have been chosen for this work. To preclude that the observed effects were strain specific, inhibition assays were performed with 4 different isolates of each species. Some amount of variability in the response to $\beta-\mathrm{LG}$ was observed among isolates within species. Additional studies involving a greater number of isolates of these and other species would provide a more comprehensive understanding of the relevance of the findings presented in this work.

Many functions already have been proposed for $\beta$-LG. Based on binding studies and tertiary structure comparisons with proteins of known function, $\beta$-LG has been proposed as a carrier of retinol and long-chain fatty acids (Pérez and Calvo, 1995). It also has been suggested that $\beta$-LG could play a role in lipid digestion by stimulating pharyngeal lipase activity (Pérez et al., 1992). Immune-related functions also have been described for $\beta$-LG. Pellegrini et al. (2004) reported that peptides obtained from $\beta-\mathrm{LG}$ by trypsin digestion displayed antibacterial activity against gram-positive bacteria. Because trypsin occurs in the gastrointestinal tract of mammals, those authors proposed a role for $\beta-L G$ in passive immune transfer to the newborn calf. Moreover, Ouwehand et al. (1997) demonstrated that $\beta$-LG is capable of inhibiting bacterial adhesion to intestinal proteins, which may indicate that $\beta$-LG could impair bacterial adhesion to the gastrointestinal epithelium of mammals. From the above examples, it follows that most biological functions attributed to $\beta$-LG are related to nourishment of the newborn calf, whether it is a source of AA, retinol and fatty acid transport, passive immunity transfer, or improvement of lipid digestion. Contrary to these functions, we report a possible role for $\beta$-LG in the secretory tissue, providing antimicrobial defense to the mammary gland against mastitis-causing agents. Amidated $\beta$-LG has been shown to display inhibitory activity against Pseudomonas sp. and Bacillus sp. strains (Pan et al., 2007). Our work, on the other hand, shows that antimicrobial activity can be exerted by native $\beta$-LG. To our knowledge, this is the first report showing antibacterial activity of native $\beta$-LG against major mastitis-causing agents. These results differ from those presented by Pan et al. (2007); the use of a commercial preparation of $\beta-\mathrm{LG}$ in those experiments could explain the reported lack of antimicrobial activity. In contrast, we used fresh milk and a mild, nondenaturing $\beta$-LG isolation protocol to ensure the preservation of the structural and functional properties of $\beta$-LG. Differences in structural features between commercial and in-lab $\beta$-LG obtained by nondenaturing isolation have been previously reported by others (de Jongh et al., 2001).

The mechanisms underlying $\beta$-LG antibacterial activity were not addressed in this work. Previous studies with isolated peptides from $\beta$-LG (Pellegrini et al., 2004) suggest that the anionic domains of $\beta$-LG could be responsible for the activity we observed. The replacement of acid with basic AA in these domains has been shown to broaden the spectrum of action toward gram-negative bacteria and to weaken the antimicrobial effect against gram-positive bacteria (Pellegrini et al., 2004). This fact highlights the importance of the anionic character of these domains on the activity and gram-specificity of $\beta$-LG. The apparent importance of the anionic character of $\beta$-LG for its antibacterial activity is consistent with our finding that its more anionic variant, $\beta$-LG A $(\mathrm{PI}=5.26)$, has higher antibacterial activity than the slightly more acidic variant, $\beta$-LG B $(\mathrm{PI}=5.34)$. Furthermore, the AA substitutions that define $\beta$-LG A and $\beta$-LG B variants are associated with changes in the surface structure of the molecule (de Jongh et al., 2001), which could contribute to explaining their differences in biological activity.

Augmented antimicrobial activity was observed when physiological concentrations of both $\beta-\mathrm{LG}$ and LF at mid lactation were coincubated with Staph. aureus isolates. This finding suggests that both proteins may act in concert to inhibit Staph. aureus growth in the mammary gland during mid lactation. Both $\beta$-LG and LF occur at high concentrations during peripartum (Pérez et al., 1990; Piccinini et al., 2007), suggesting that these proteins also could play a relevant function during the first days of lactation, when other effectors of innate immunity are known to be impaired (Piccinini et al., 2004; Sordillo et al., 1997, 2009). Taken together, our results suggest that by cooperating in Staph. aureus inhibition and exerting differential activities toward $E$. coli and Strep. uberis, $\beta-\mathrm{LG}$ and LF can complement each other in the defense of the mammary gland against bacterial infection.

\section{ACKNOWLEDGMENTS}

This work was supported by grants from Consejo Nacional de Investigaciones Científicas y Tecnológicas 
(CONICET) PIP 5390 and ANPCyT 21-34413. The authors are indebted to U. Bussmann (Instituto de Biología y Medicina Experimental, CONICET 1428, Buenos Aires, Argentina), for critical reading of the manuscript. L. Chaneton is a fellow from CONICET; L. E. Bussmann is an established investigator from the same institution

\section{REFERENCES}

Arnold, R. R., J. E. Russell, W. J. Champion, M. Brewer, and J. J. Gauthier. 1982. Bactericidal activity of human lactoferrin: Differentiation from the stasis of iron deprivation. Infect. Immun. 35:792-799.

Bovenhuis, H., J. A. van Arendonk, and S. Korver. 1992. Associations between milk protein polymorphisms and milk production traits. J. Dairy Sci. 75:2549-2559.

Calvinho, L., and L. Tirante. 2005. Prevalencia de microorganismos patógenos de mastitis bovina y evolución del estado de salud de la glándula mamaria en Argentina en los últimos 25 años. Revista FAVE 4:29-40.

Chaneton, L., L. Tirante, J. Maito, J. Chaves, and L. E. Bussmann. 2008. Relationship between milk lactoferrin and etiological agent in the mastitic bovine mammary gland. J. Dairy Sci. 91:18651873.

de Jongh, H. H., T. Groneveld, and J. de Groot. 2001. Mild isolation procedure discloses new protein structural properties of beta-lactoglobulin. J. Dairy Sci. 84:562-571.

Dinsmore, R. P., P. B. English, R. N. Gonzalez, and P. M. Sears. 1992. Use of augmented cultural techniques in the diagnosis of the bacterial cause of clinical bovine mastitis. J. Dairy Sci. 75:2706-2712.

Ellison, R. T. III, and T. J. Giehl. 1991. Killing of gram-negative bacteria by lactoferrin and lysozyme. J. Clin. Invest. 88:1080-1091.

Flower, D. R., A. C. North, and C. E. Sansom. 2000. The lipocalin protein family: Structural and sequence overview. Biochim. Biophys. Acta 1482:9-24.

Gigli, I., D. O. Maizon, and L. E. Bussmann. 2004. Frecuencia genotípica de beta-lactoglobulina en relacion con mastitis clinica. J. Basic Appl. Genet. 16:125.

Heck, J. M., A. Schennink, H. J. van Valenberg, H. Bovenhuis, M. H. Visker, J. A. van Arendonk, and A. C. van Hooijdonk. 2009. Effects of milk protein variants on the protein composition of bovine milk. J. Dairy Sci. 92:1192-1202.

Hogan, J. S., R. S. Gonzáles, R. J. Harmon, S. C. Nickerson, S. P. Oliver, J. W. Pankey, and K. L. Smith. 1999. Laboratory Handbook on Bovine Mastitis. National Mastitis Council Inc., Madison, WI.

Kontopidis, G., C. Holt, and L. Sawyer. 2004. Invited review: $\beta$-Lactoglobulin: Binding properties, structure, and function. J. Dairy Sci. 87:785-796.

Kutila, T., S. Pyorala, H. Saloniemi, and L. Kaartinen. 2003. Antibacterial effect of bovine lactoferrin against udder pathogens. Acta Vet. Scand. 44:35-42.

Laemmli, U. K. 1970. Cleavage of structural proteins during the assembly of the head of bacteriophage T4. Nature 227:680-685.

Ouwehand, A. C., S. J. Salminen, M. Skurnik, and P. L. Conway. 1997. Inhibition of pathogen adhesion by $\beta$-lactoglobulin. Int. Dairy J. 7:685-692.

Oviedo-Boyso, J., J. J. Valdez-Alarcon, M. Cajero-Juarez, A. OchoaZarzosa, J. E. Lopez-Meza, A. Bravo-Patino, and V. M. Baiza-
bal-Aguirre. 2007. Innate immune response of bovine mammary gland to pathogenic bacteria responsible for mastitis. J. Infect. 54:399-409.

Pan, Y., B. Shiell, J. Wan, M. J. Coventry, W. P. Michalsky, A. Lee, and H. Roginsky. 2007. The molecular characterisation and antimicrobial properties of amidated bovine b-lactoglobulin. Int. Dairy J. 17:1450-1459.

Pellegrini, A., A. J. Hulsmeier, P. Hunziker, and U. Thomas. 2004 Proteolytic fragments of ovalbumin display antimicrobial activity. Biochim. Biophys. Acta 1672:76-85.

Pérez, M. D., and M. Calvo. 1995. Interaction of beta-lactoglobulin with retinol and fatty acids and its role as a possible biological function for this protein: A review. J. Dairy Sci. 78:978-988.

Pérez, M. D., L. Sanchez, P. Aranda, J. M. Ena, R. Oria, and M. Calvo. 1990. Synthesis and evolution of concentration of beta-lactoglobulin and alpha-lactalbumin from cow and sheep colostrum and milk throughout early lactation. Cell. Mol. Biol. 36:205-212.

Pérez, M. D., L. Sanchez, P. Aranda, J. M. Ena, R. Oria, and M. Calvo. 1992. Effect of beta-lactoglobulin on the activity of pregastric lipase. A possible role for this protein in ruminant milk. Biochim. Biophys. Acta 1123:151-155.

Piccinini, R., E. Binda, M. Belotti, G. Casirani, and A. Zecconi. 2004 The evaluation of non-specific immune status of heifers in field conditions during the periparturient period. Vet. Res. 35:539-550.

Piccinini, R., E. Binda, M. Belotti, V. Dapra, and A. Zecconi. 2007. Evaluation of milk components during whole lactation in healthy quarters. J. Dairy Res. 74:226-232.

Qin, B. Y., M. C. Bewley, L. K. Creamer, E. N. Baker, and G. B. Jameson. 1999. Functional implications of structural differences between variants $\mathrm{A}$ and $\mathrm{B}$ of bovine beta-lactoglobulin. Protein Sci. 8:75-83.

Rainard, P. 1986. Bacteriostatic activity of bovine milk lactoferrin against mastitic bacteria. Vet. Microbiol. 11:387-392.

Sawyer, L., and G. Kontopidis. 2000. The core lipocalin, bovine betalactoglobulin. Biochim. Biophys. Acta 1482:136-148.

Schägger, H., and G. von Jagow. 1987. Tricine-sodium dodecyl sulfatepolyacrylamide gel electrophoresis for the separation of proteins in the range from 1 to $100 \mathrm{kDa}$. Anal. Biochem. 166:368-379.

Schukken, Y. H., F. J. Grommers, J. A. Smit, D. Vandegeer, and A. Brand. 1989. Effect of freezing on bacteriologic culturing of mastitis milk samples. J. Dairy Sci. 72:1900-1906.

Seegers, H., C. Fourichon, and F. Beaudeau. 2003. Production effects related to mastitis and mastitis economics in dairy cattle herds. Vet. Res. 34:475-491.

Sordillo, L. M., G. A. Contreras, and S. L. Aitken. 2009. Metabolic factors affecting the inflammatory response of periparturient dairy cows. Anim. Health Res. Rev. 10:53-63.

Sordillo, L. M., K. Shafer-Weaver, and D. DeRosa. 1997. Immunobiology of the mammary gland. J. Dairy Sci. 80:1851-1865.

Sordillo, L. M., and K. L. Streicher. 2002. Mammary gland immunity and mastitis susceptibility. J. Mammary Gland Biol. Neoplasia 7:135-146.

Spik, G., A. Cheron, J. Montreuil, and J. M. Dolby. 1978. Bacteriostasis of a milk-sensitive strain of Escherichia coli by immunoglobulins and iron-binding proteins in association. Immunology $35: 663-671$.

Watts, J. L. 1988. Etiological agents of bovine mastitis. Vet. Microbiol. 16:41-66.

Ye, X., S. Yoshida, and T. B. Ng. 2000. Isolation of lactoperoxidase, lactoferrin, alpha-lactalbumin, beta-lactoglobulin B and beta-lactoglobulin A from bovine rennet whey using ion exchange chromatography. Int. J. Biochem. Cell Biol. 32:1143-1150. 